\title{
Distributional patterns of herbivore megamammals during the Late Pleistocene of South America
}

\author{
VALÉRIA GALLO $^{1}$, LEONARDO S. AVILLA ${ }^{2}$, RODRIGO C.L. PEREIRA ${ }^{1,2}$ and BRUNO A. ABSOLON ${ }^{1,2}$ \\ ${ }^{1}$ Universidade do Estado do Rio de Janeiro, Instituto de Biologia, Departamento de Zoologia, \\ Laboratório de Sistemática e Biogeografia, Rua São Francisco Xavier, 524, Maracanã, 20550-013 Rio de Janeiro, RJ, Brasil \\ ${ }^{2}$ Universidade Federal do Estado do Rio de Janeiro, Instituto de Biociências, Departamento de Zoologia, \\ Laboratório de Mastozoologia, Avenida Pasteur, 458, Urca, 22290-240 Rio de Janeiro, RJ, Brasil
}

Manuscript received on October 10, 2012; accepted for publication on January 21, 2013

\begin{abstract}
The geographic distribution of 27 species of the South American megafauna of herbivore mammals during the Late Pleistocene was analyzed in order to identify their distributional patterns. The distribution of the species was studied using the panbiogeographical method of track analysis. Six generalized tracks (GTs) and two biogeographic nodes were obtained. The GTs did not completely superpose with the areas of open savanna present in Pleistocene, nor with the biotic tracks of some arthropods typical of arid climate, indicating that these animals avoided arid environment. Overall, the GTs coincided with some biogeographic provinces defined on the basis of living taxa, indicating that certain current distributional patterns already existed in Pleistocene. The biogeographic nodes coincided with the borders between the main vegetal formations of the Pleistocene, showing that the type of vegetation had great influence in the distribution of the mammalian megafauna. The node 1 confirmed the existence of contact zones between paleobiogeographic regions near Argentina-Uruguay border. The node 2 connects the Brazilian Intertropical regions.
\end{abstract}

Key words: Distributional patterns, Historical Biogeography, Panbiogeography, Megafauna, Late Pleistocene, South America.

\section{INTRODUCTION}

During the Pleistocene, South America was inhabited by numerous large mammals that became extinct in the Pleistocene-Holocene transition. The causes of the extinction are still debatable, but the most acceptable are the drastic change in the vegetation after the end of the last maximum glacial, direct and indirect human impacts, and the introduction of diseases by

Correspondence to: Valéria Gallo

E-mail: gallo@uerj.br humans or by invasive species (Câmara 2006, Koch and Barnosky 2006, Cione et al. 2009).

According to the traditional view, the native South American Pleistocene megafauna was affected by the dispersion of North American species during the biogeographic event known as Great American Biotic Interchange (GABI). In this event, several taxa (not only mammals) expanded their distribution to both continents. It occurred approximately $2.7 \mathrm{Ma}$, due the emergence of the Isthmus of Panama, and it had a great influence 
in the composition of the extant South American fauna (Webb 2006, Woodburne 2010). However, according to Simpson $(1950,1980)$ and Webb (2006), the taxa of mammals from North America that participated in the interchange had a higher success in South America than the South American invasive taxa in North America. This asymmetry could be explained by the fact that the northern taxa had a long and wide-ranging history from the time of Eurasia. Only four genera of South American mammals (i.e., Didelphis, Dasypus, Erethizon, and Trichechus) survived in the North America (Webb 2006).

The GABI was not the only event of interchange of taxa between North and South America. Remains of some taxa of South American ground sloth were found in North America in more early ages than the emergence of the Isthmus, and remains of some typical Holarctic mammals, such as Carnivora Procyonidae, and a gomphothere and Tayassuidae were found in a Late Miocene locality of Peru (Campbell Jr et al. 2000, 2010, Webb 2006). The groups that expanded their distribution to both continents before this emergence are considered as isolated cases of dispersion, also because of the gap of 6 Ma. Therefore, they did not make part of the GABI (Marshall 1988). Central America was not only a "corridor" during the Interchange, but it has also an important role in this event. Some Holarctic taxa (e.g. Bison) were not able to cross Central America (Webb and Rancy 1996), while others (e.g. Cerdocyon, Neochoerus, Glossotherium) spent a longer time in the region before they could expand their distribution, which is called "holding pens", indicating that some of these taxa probably differentiated before crossing Central America (Woodburne et al. 2006, Woodburne 2010).

Except for some groups, several doubts and discussions remain regarding taxonomy and ecology of the American Pleistocene megafauna, as well as how the GABI affected the distribution of that fauna. Although a lot of studies had already been published in order to answer these doubts, these studies are mostly related to ecology and taphonomy (e.g. Sánchez et al. 2004, Mendoza 2007). By contrast, there are few studies accomplished about the distributional patterns of the megafauna, especially with a panbiogeographical approach.

The goal of the present study is to contribute to the knowledge of the South American megafauna, using the panbiogeographical method of track analysis. This is a first attempt to analyze the distributional pattern of the South American Late Pleistocene herbivore megafauna taxa. It shows preliminary results included in R.C.L. Pereira et al. (unpublished data) and R.C.L. Pereira (unpublished data).

The panbiogeographical method of track analysis, developed by Croizat (1958, 1964), and later expanded and quantified by Page (1987), Craw et al. (1999), and Echeverry and Morrone (2010), allows identification of congruent patterns of geographic distribution if phylogenetic information of the studied taxa is not available. This method is especially useful in paleontology, due to phylogenetic data of the most of extinct groups are dubious or even incomplete. Also, it is a tool potentially useful to identify distributional patterns (e.g. Craw 1982, Croizat 1984, Page 1987, Morrone 2001) and some recent studies confirm the validity of the method to be applied to living and extinct species (e.g. Morrone 2006, Gallo et al. 2007, 2010, Alzate et al. 2008, Cavalcanti and Gallo 2008, Arzamendia and Giraudo 2009, Corona et al. 2009, Espinosa-Pérez et al. 2009, Maya-Martínez et al. 2011).

\section{MATERIALS AND METHODS}

\section{DATA SET}

In this study, the distribution of the following genera was analyzed: Glossotherium, Lestodon, 
Mylodon, and Scelidotherium (Xenarthra, Mylodontidae); Eremotherium and Megatherium (Xenarthra, Megatheriidae); Pampatherium (Xenarthra, Pampatheriidae); Glyptotherium, Glyptodon, Hoplophorus, Panochthus, and Parapanochthus (Xenarthra, Glyptodontidae); Cuvieronius and Notiomastodon (Proboscidea, Gomphotheriidae); Equus and Hippidion (Perissodactyla, Equidae); Hemiauchenia and Palaeolama (Artiodactyla, Camelidae); and Macrauchenia (Litopterna, Macrauchenidae).

The number of localities is based on a comprehensive search in the literature, supplemented by the available records of online databases of several scientific institutions, as well as the website The Paleobiology Database (http://www.paleodb.org/ cgi-bin/bridge.pl). We found a total of 549 localities distributed in this decreasing order: Notiomastodon (95); Cuvieronius (46); Glossotherium (46); Eremotherium (42); Equus (40); Pampatherium (33); Glyptodon (30); Hippidion (27); Megatherium (27); Lestodon (24); Glyptotherium (23); Hemiauchenia (23); Panochthus (23); Mylodon (19); Palaeolama (18); Macrauchenia (14); Scelidotherium (9); Hoplophorus (6); Parapanochthus (4).

Although some of the fossils and localities analyzed do not have a detailed dating definition, we assume that all included data are from the Late Pleistocene.

\section{TRACK ANALYSIS}

The panbiogeographical method of track analysis consists basically of plotting locality records of different taxa on maps and connecting them using lines following a criterion of minimum distance, to constitute individual tracks (distribution areas). These tracks are superimposed and the coincidence of them corresponds to a generalized track (areas of endemism), providing a spatial criterion to biogeographic homology (Morrone 2001) and allowing to infer the existence of an ancestral biota widespread in the past and later fragmented by vicariant events. When two or more generalized tracks converge or superimpose in an area, a biogeographic node is determined, implying that different ancestral biotas interrelated, possibly in different geologic times, and formed a composite or hybrid area. Furthermore, the nodes may represent endemism, high diversity, and distribution boundaries (Craw et al. 1999, Grehan 2001, Heads 2004, Morrone 2004, 2009).

Individual tracks were constructed for each species by plotting the localities on present-day world maps with the help of the software ArcView v3.2 (ESRI 1999) and connecting them by minimum spanning trees (Page 1987) using the Trazos2004 extension (Rojas 2007). Generalized tracks and biogeographic nodes were drawn by hand.

\section{RESULTS}

From the 27 individual tracks (i.e., Cuvieronius hyodon, Equus andium, E. insulatus, E. neogeus, E. santaelenae, Eremotherium laurillardii, Glossotherium robustum, Glyptodon clavipes, Glyptotherium sp., Hemiauchenia paradoxa, Hippidion devillei, H. principale, H. saldiasi, Hoplophorus euphractus, Lestodon armatus, Macrauchenia patachonica, Megatherium americanum, M. medinae, Mylodon darwini, Notiomastodon platensis, Palaeolama major, Pampatherium humboldti, P. typum, Panochthus greslebini, P. tuberculatus, Parapanochthus jaguaribensis, and Scelidotherium leptocephalus) (Figs. 1-21), six generalized tracks (GTs) were obtained (Fig. 22). These are defined as follows: GT1, Transandine Peru (including Eremotherium laurilardii, Equus santaelenae, Equus andium, and Glossotherium robustum); GT2, Cisandine Peru/ Puna (including Cuvieronius hyodon and Equus insulatus); GT3, Santiago (including Hippidion saldiasi and Megatherium medinae); GT4, Chaco/Pampas/Northwest Uruguay (including Pampatherium typum, Panochthus tuberculatus, Lestodon armatus, Glyptodon clavipes, 
Hemiauchenia paradoxa, Mylodon darwini, Macrauchenia patachonica, and Megatherium americanum); GT5, Intertropical Region/ Southeastern Brazil (including Pampatherium humboldtii, Notiomastodon platensis, Hippidion principale, and Equus neogeus); and GT6, Intertropical Region/Northeastern Brazil) (including Palaeolama major, Glyptotherium sp., Panochthus greslebini, Parapanochthus jaguaribensis, and Hoplophorus euphractus). Hippidion devillei and Scelidotherium leptocephalus did not participate in the composition of any generalized track. The GTs regions were recognized and named based on Morrone (2006) biogeographic province definitions.

Two biogeographic nodes were found: node 1 , in the intersection of GTs 4 and 5, in the frontier of Uruguay-Brazil (Grassland/Steppe sensu de Vivo and Carmignotto 2004); node 2, in the intersection of GTs 5 and 6 , between the Brazilian states of Sergipe and Alagoas, near the São Francisco River.

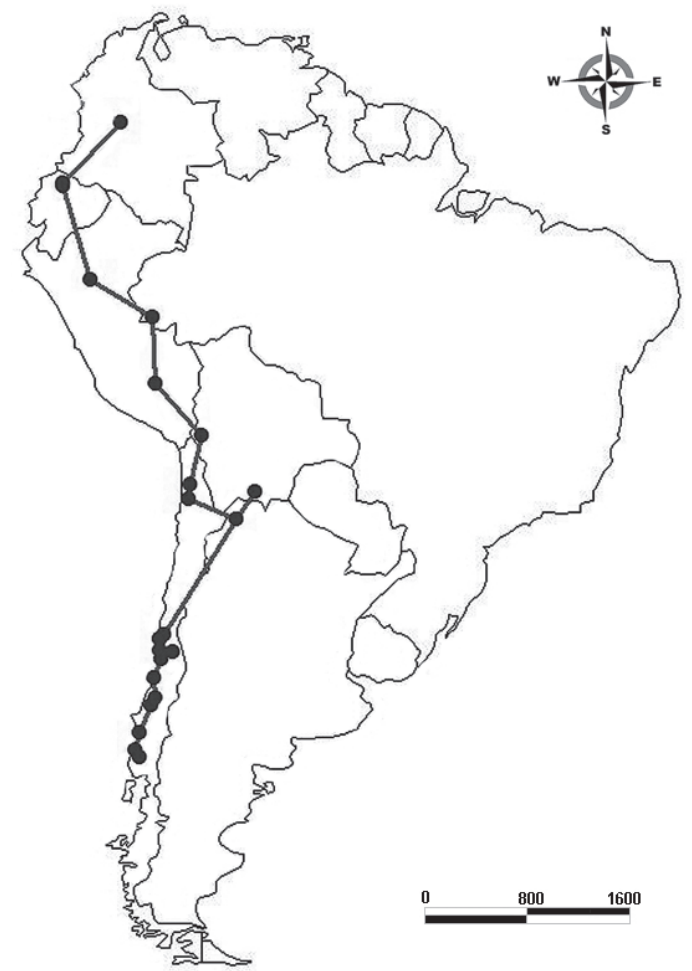

Fig. 1 - Individual track of Cuvieronius hyodon.

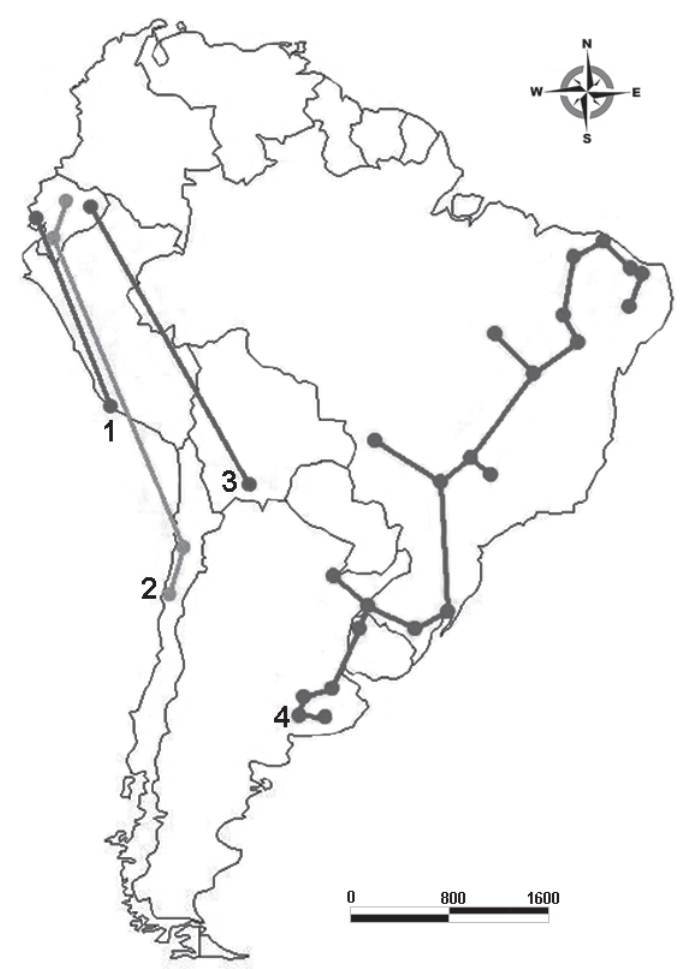

Fig. 2 - Individual tracks of Equus (1 - Equus andium; 2 - E. insulatus; 3 - E. neogeus; 4 - E. santaelenae).

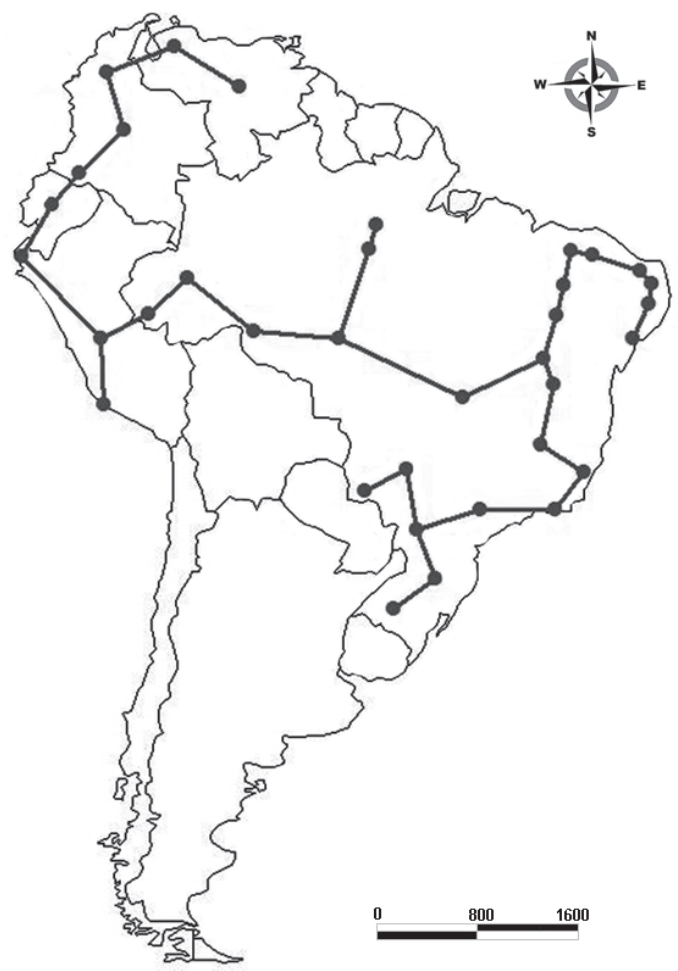

Fig. 3 - Individual track of Eremotherium laurillardii. 


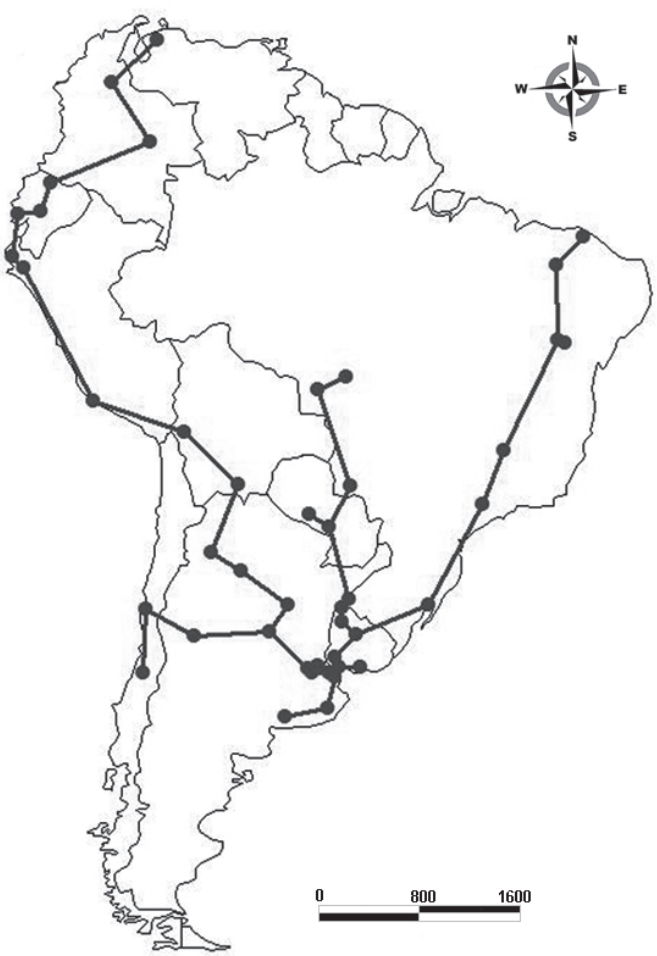

Fig. 4 - Individual track of Glossotherium robustum.

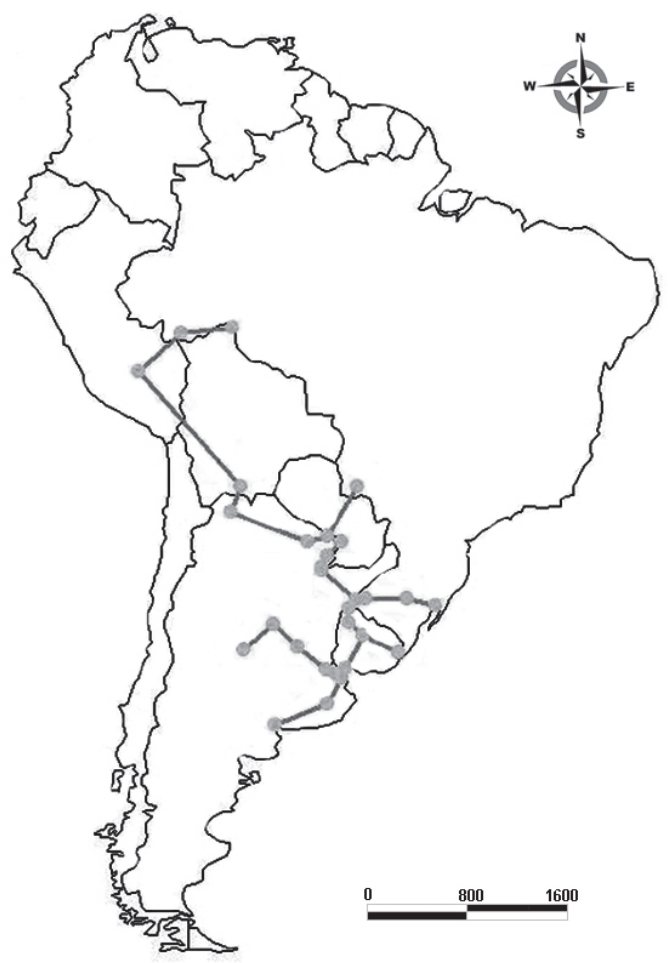

Fig. 5 - Individual track of Glyptodon clavipes.

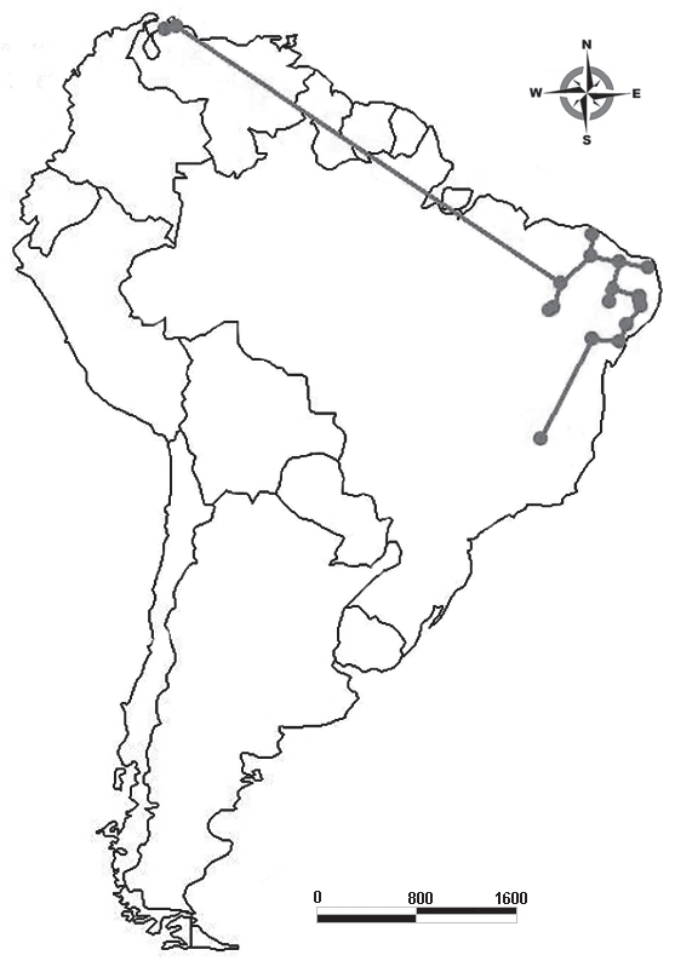

Fig. 6 - Individual track of Glyptotherium sp.

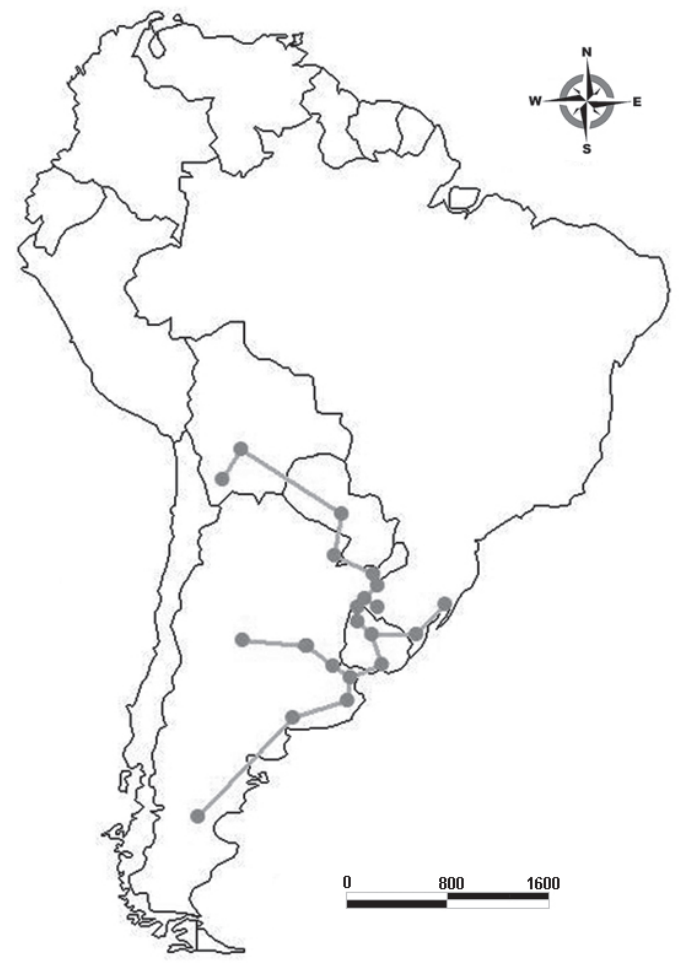

Fig. 7 - Individual track of Hemiauchenia paradoxa. 


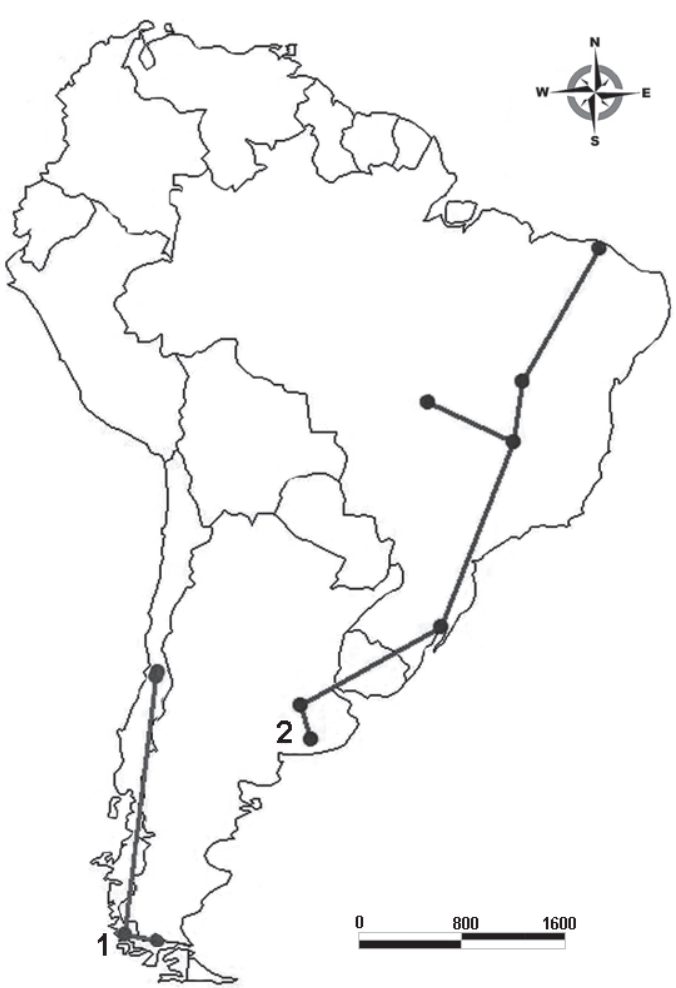

Fig. 8 - Individual tracks of Hippidion (1 - Hippidion saldiasi; 2 - H. principale).

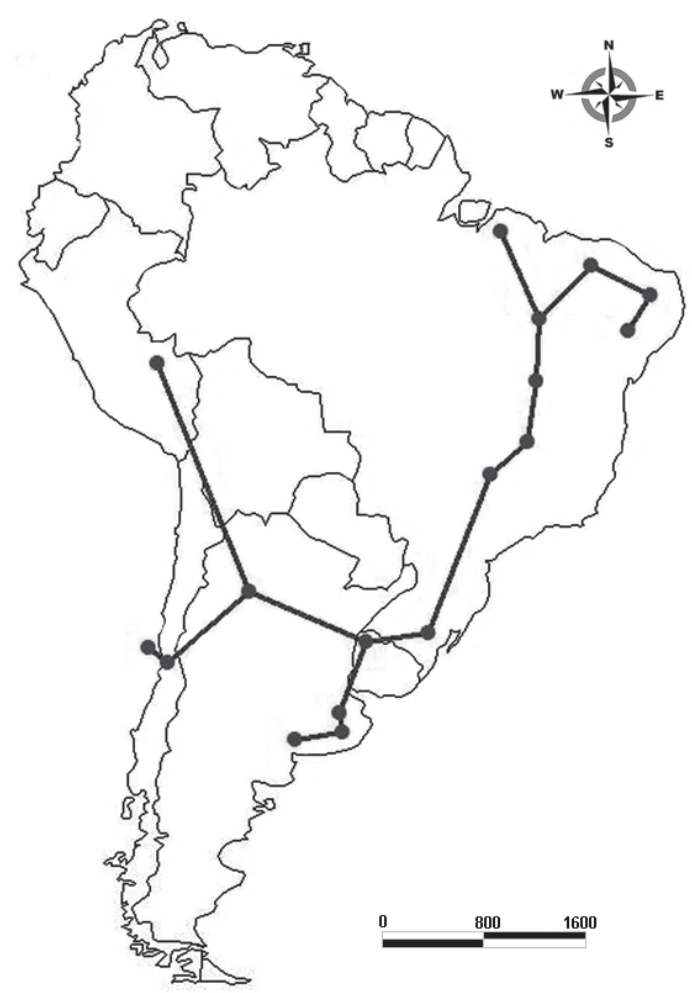

Fig. 9 - Individual track of Hippidion devillei.

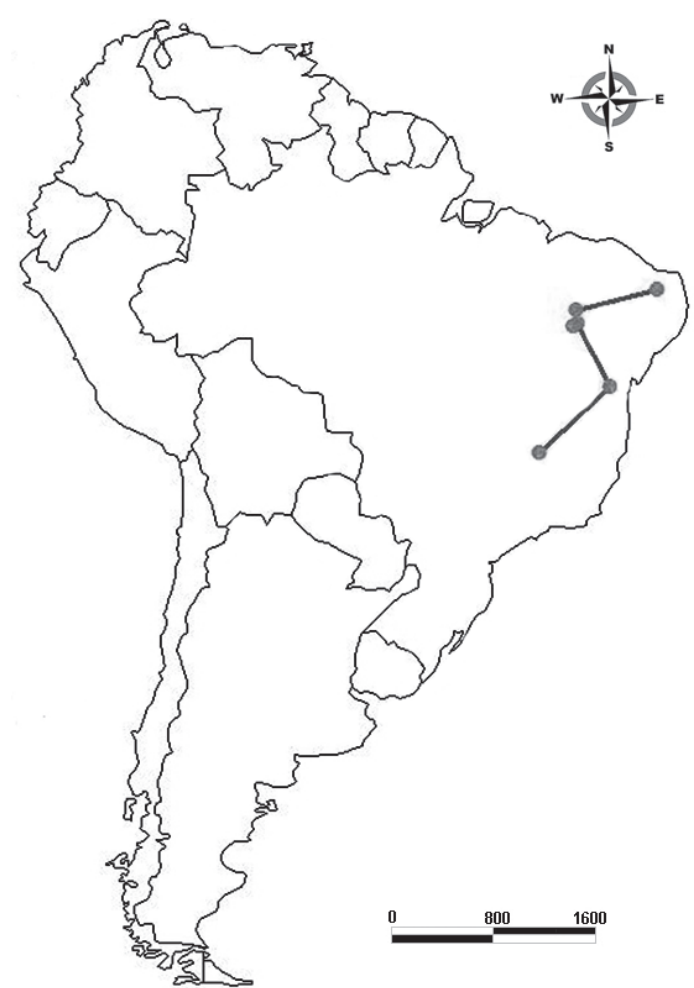

Fig. 10 - Individual track of Hoplophorus euphractus.

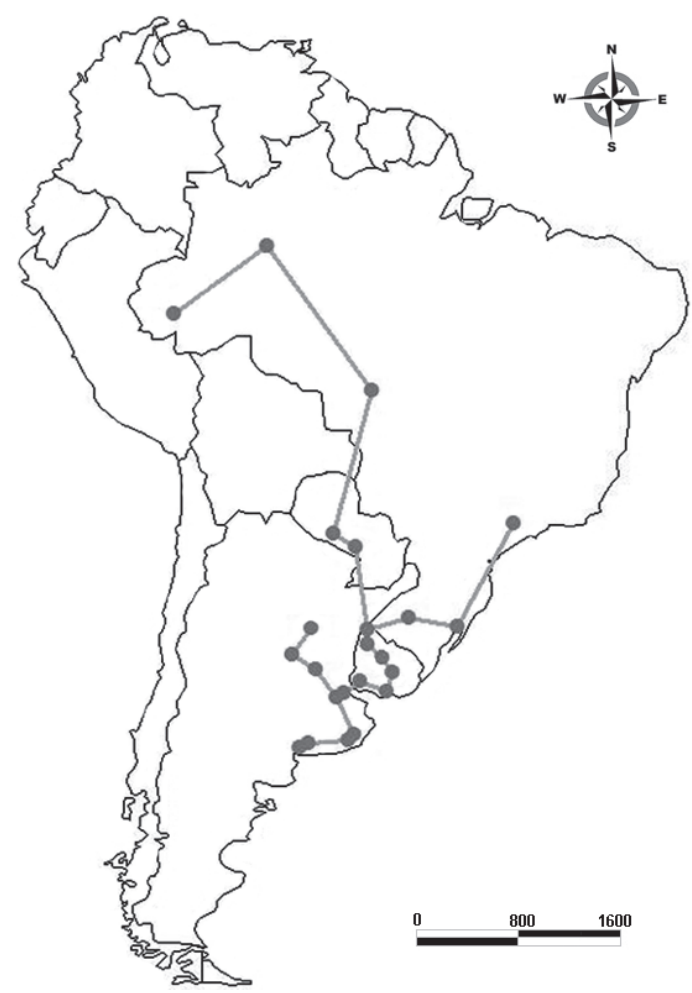

Fig. 11 - Individual track of Lestodon armatus. 


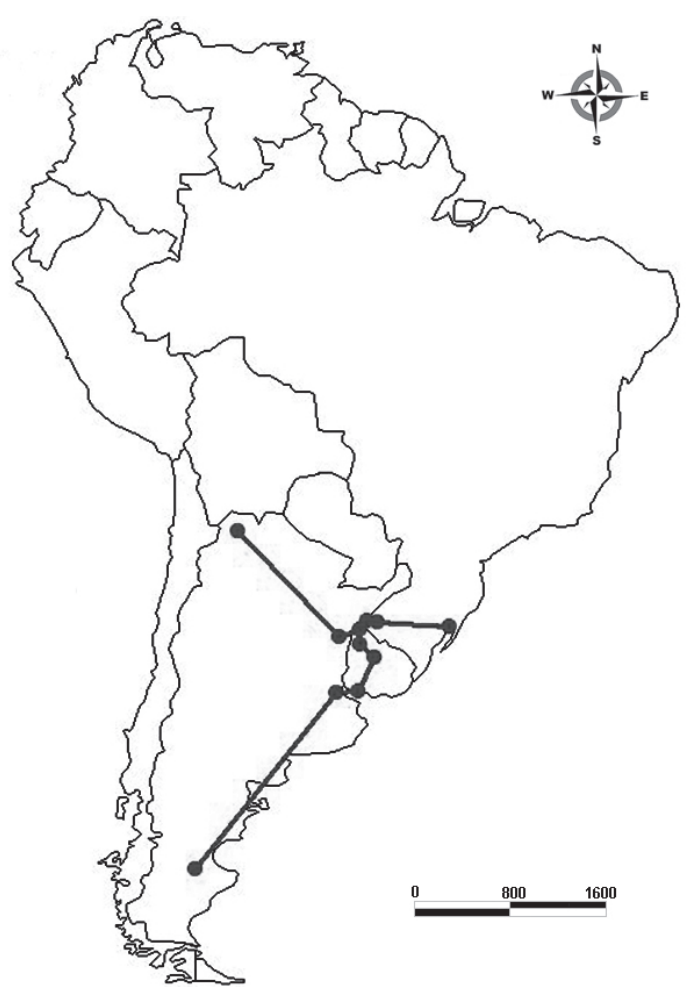

Fig. 12 - Individual track of Macrauchenia patachonica.

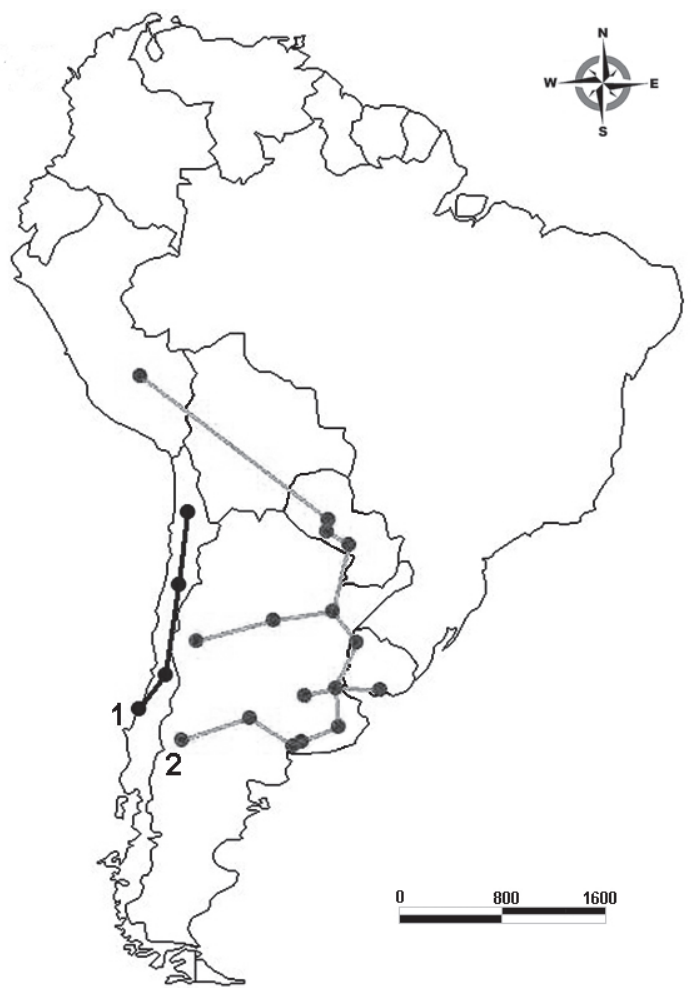

Fig. 13 - Individual tracks of Megatherium (1 - Megatherium medinae; 2 - M. americanum).

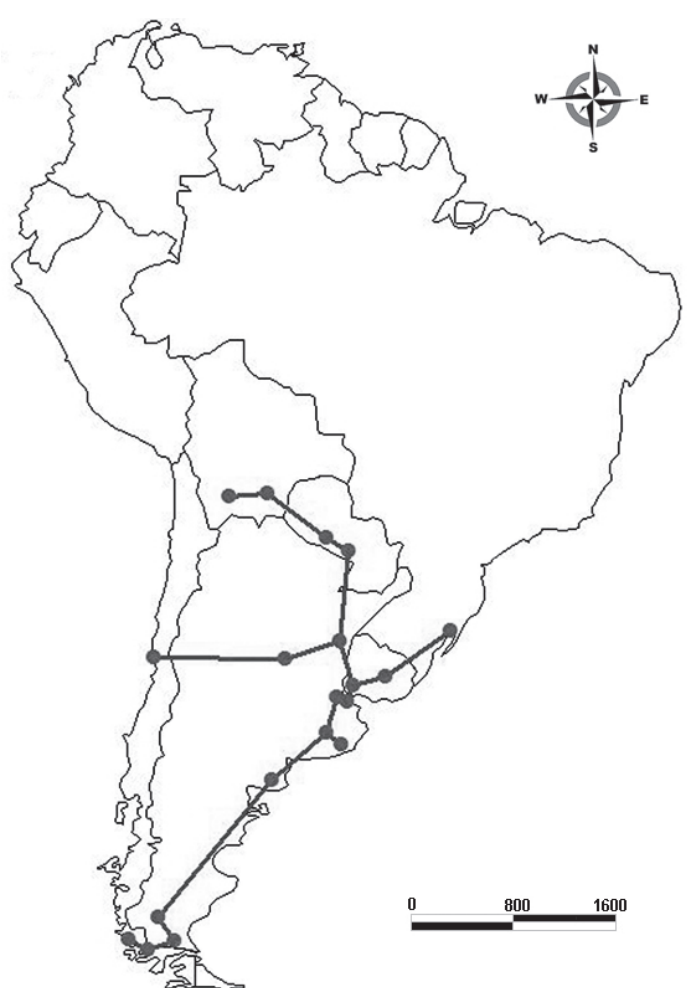

Fig. 14 - Individual track of Mylodon darwini.

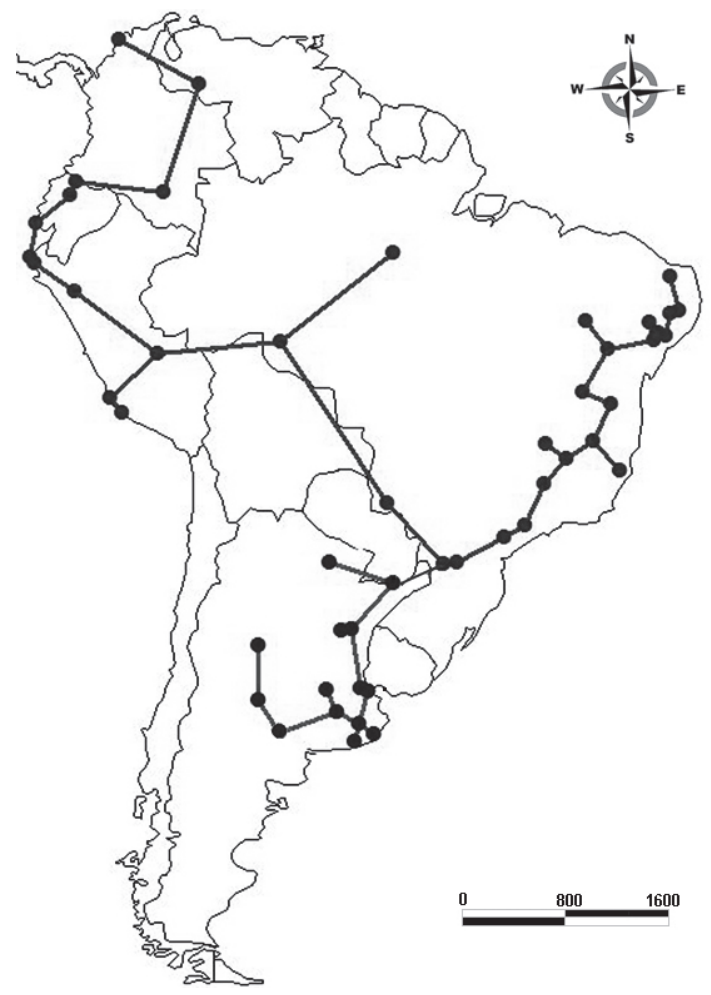

Fig. 15 - Individual track of Notiomastodon platensis. 


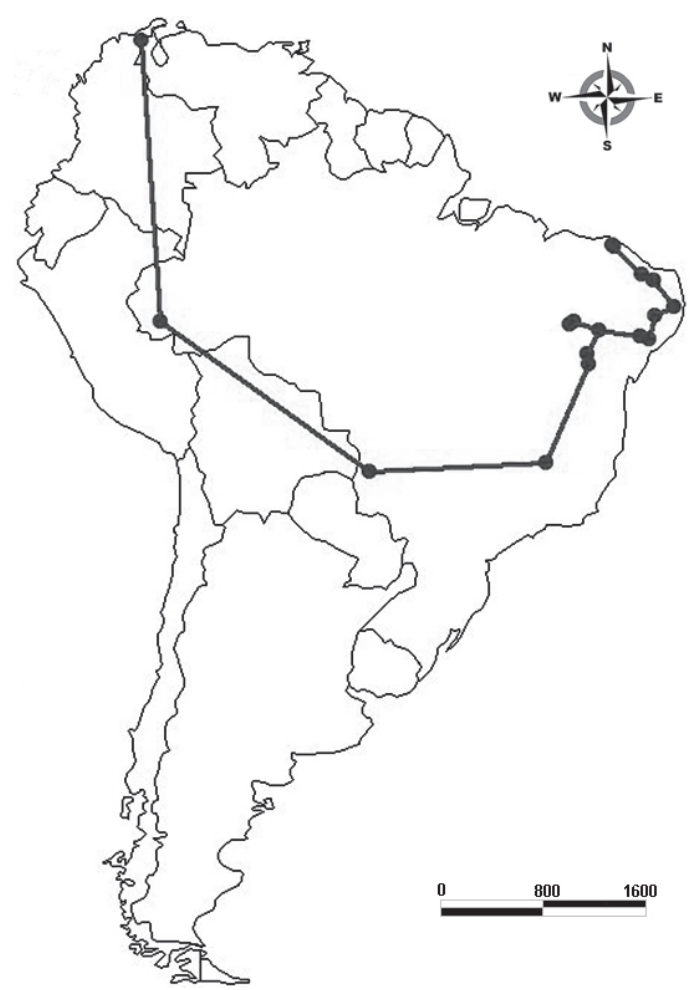

Fig. 16 - Individual track of Palaeolama major.

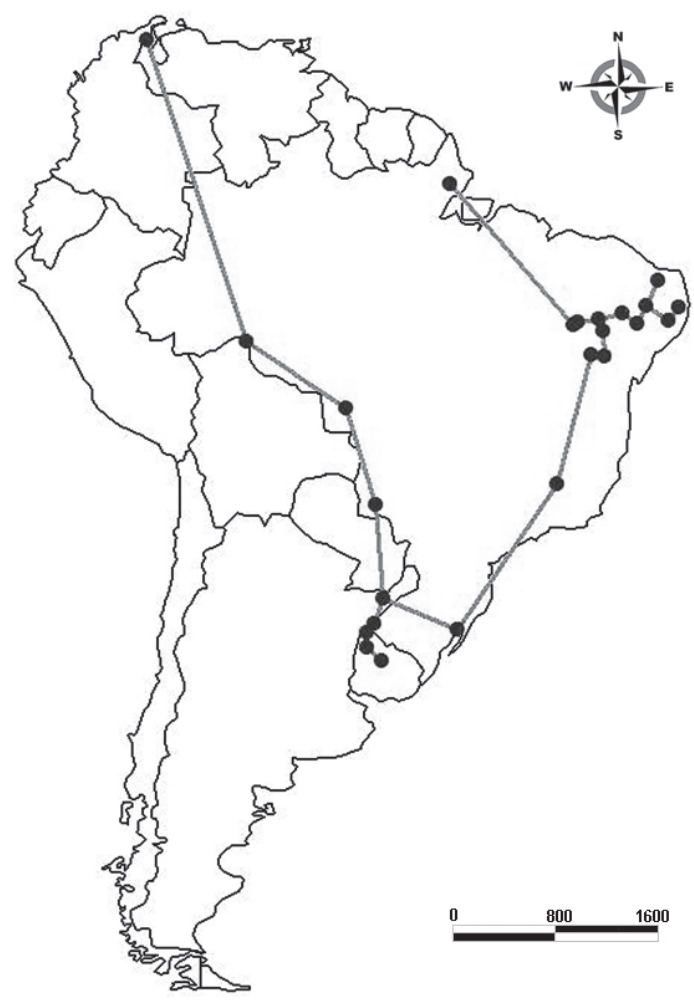

Fig. 17 - Individual track of Pampatherium humboldti.

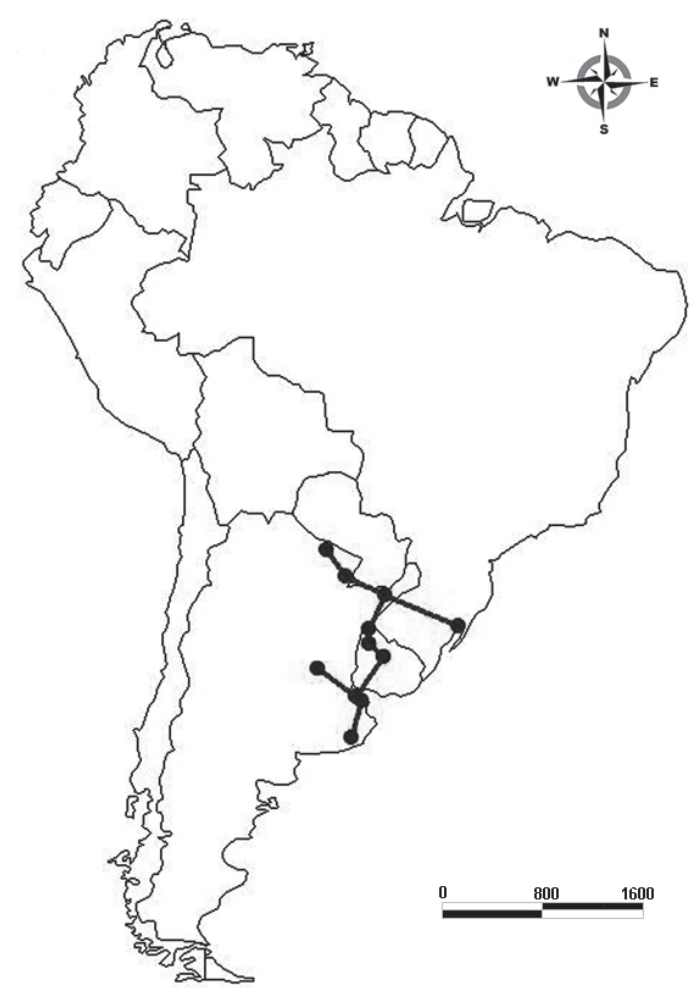

Fig. 18 - Individual track of P. typum.

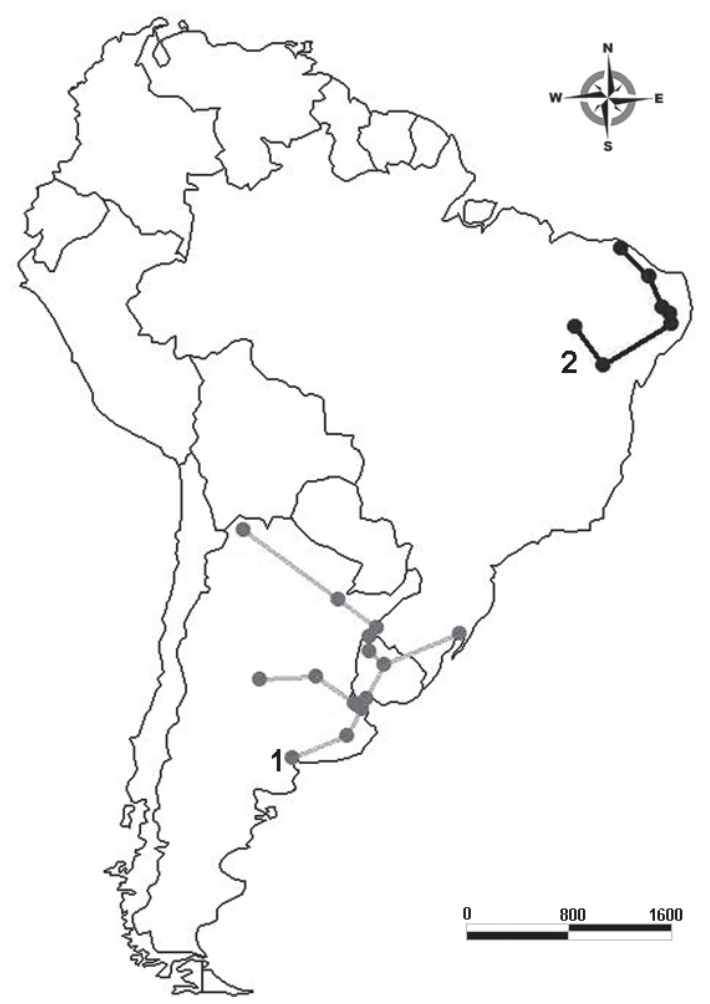

Fig. 19 - Individual tracks of Panochthus (1 - Panochthus tuberculatus; 2 - P. greslebini). 


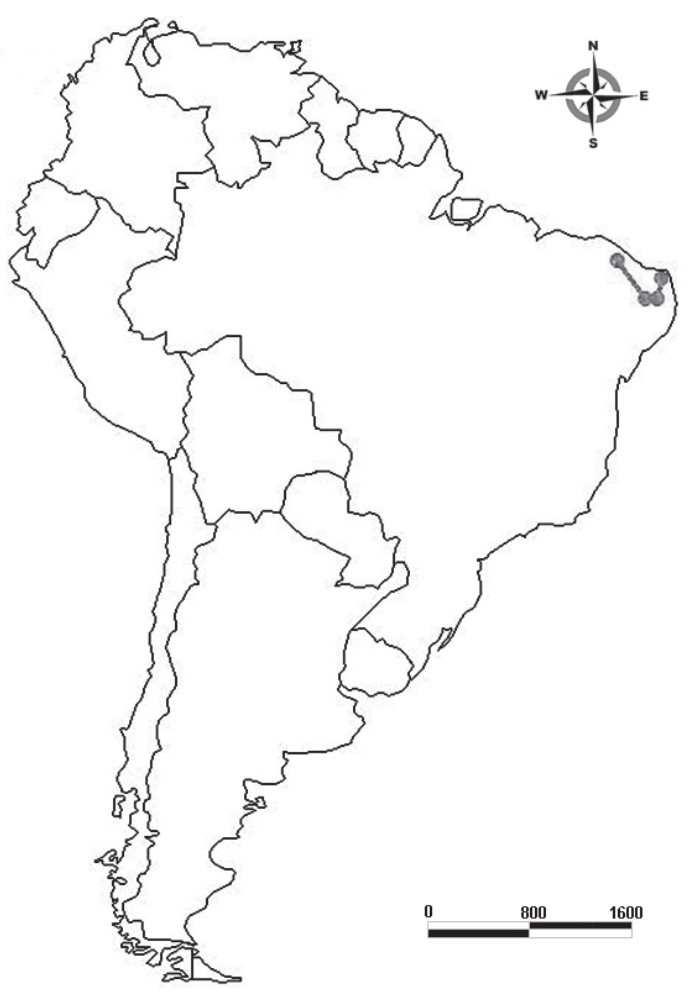

Fig. 20 - Individual track of Parapanochthus jaguaribensis.

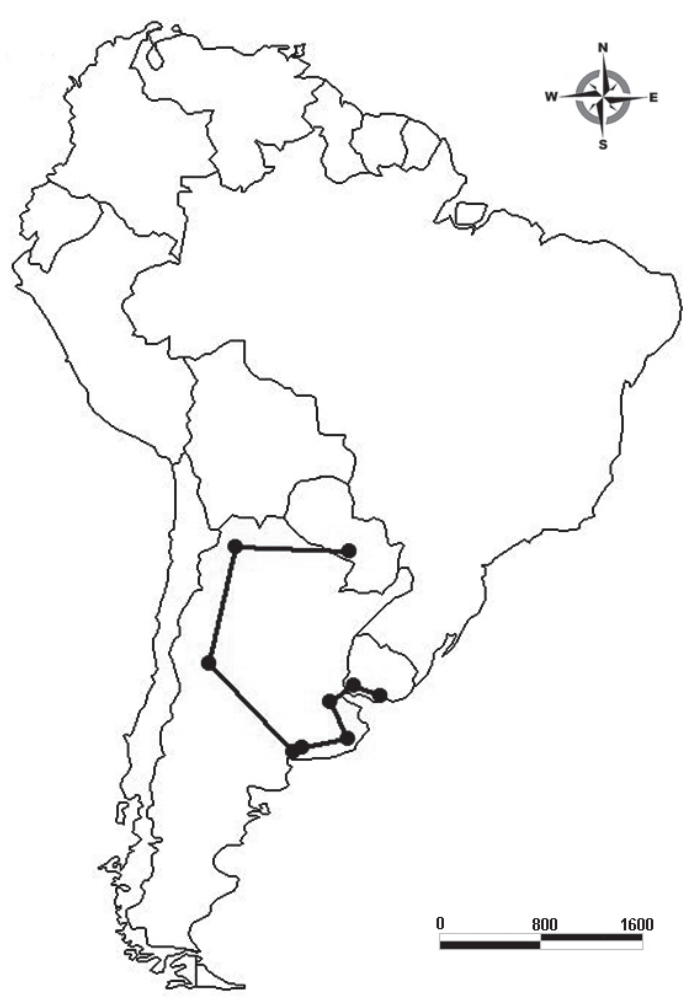

Fig. 21 - Individual track of Scelidotherium leptocephalus.

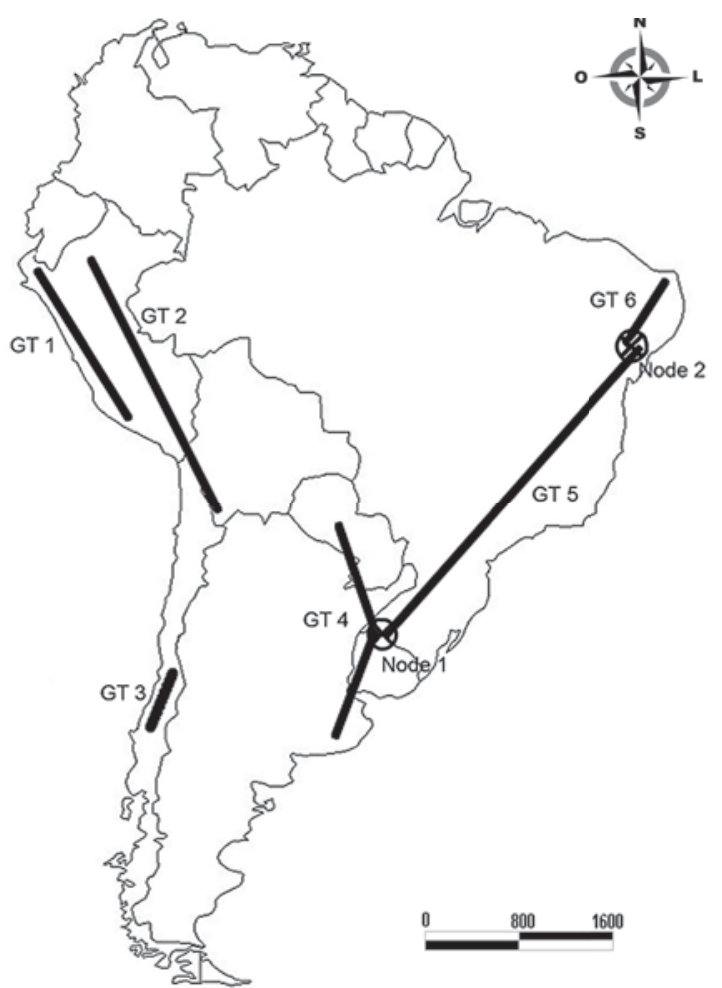

Fig. 22 - Generalized tracks and nodes.

\section{DISCUSSION}

Several studies (e.g. Salgado-Labouriau et al. 1998, Heine 2000, Behling et al. 2002) indicate that climate and vegetation of South America during the Pleistocene were different when compared to the present. Only in the Late Pleistocene the levels of temperature and humidity began to approximate to the present-day levels.

Comparing the GTs map with the one of distributional pattern of vegetation in South America during the Pleistocene (de Vivo and Carmignotto 2004) (Fig. 23), we concluded that herbivore megamammals avoided the two great areas of open savanna present in the Late Pleistocene. Yet, the GTs were not superimposed with the two biotic tracks defined by Roig-Juñent et al. (2003, 2006) for living arthropods typical of xeric natural areas of South America (Fig. 24), confirming that the herbivore megamammals avoid arid or semi-arid ecosystems. 


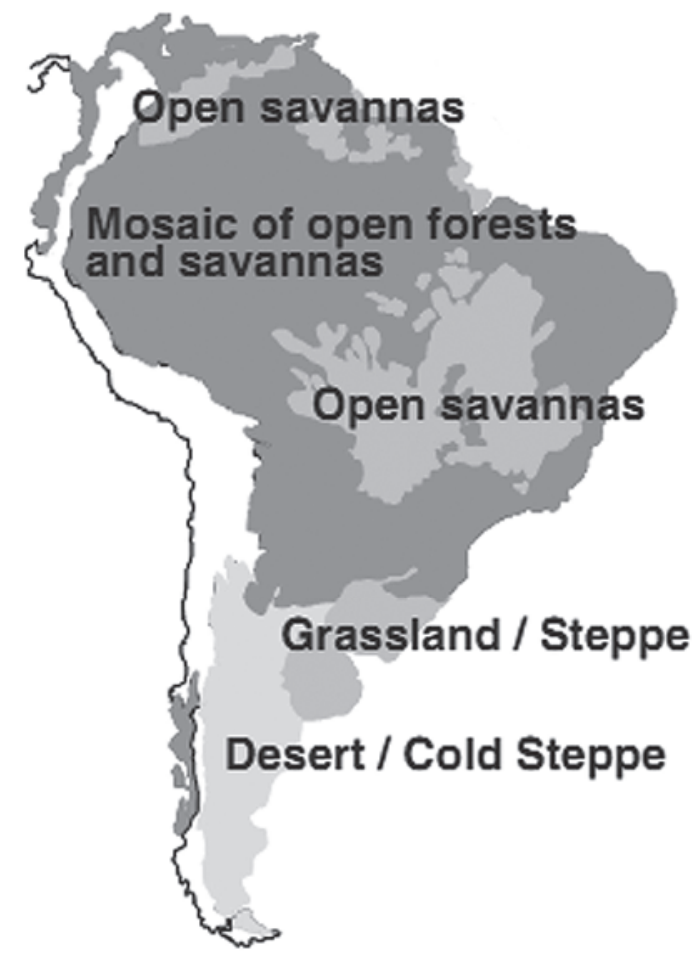

Fig. 23 - Distributional pattern of vegetation during the Pleistocene (modified from de Vivo and Carmignotto 2004).

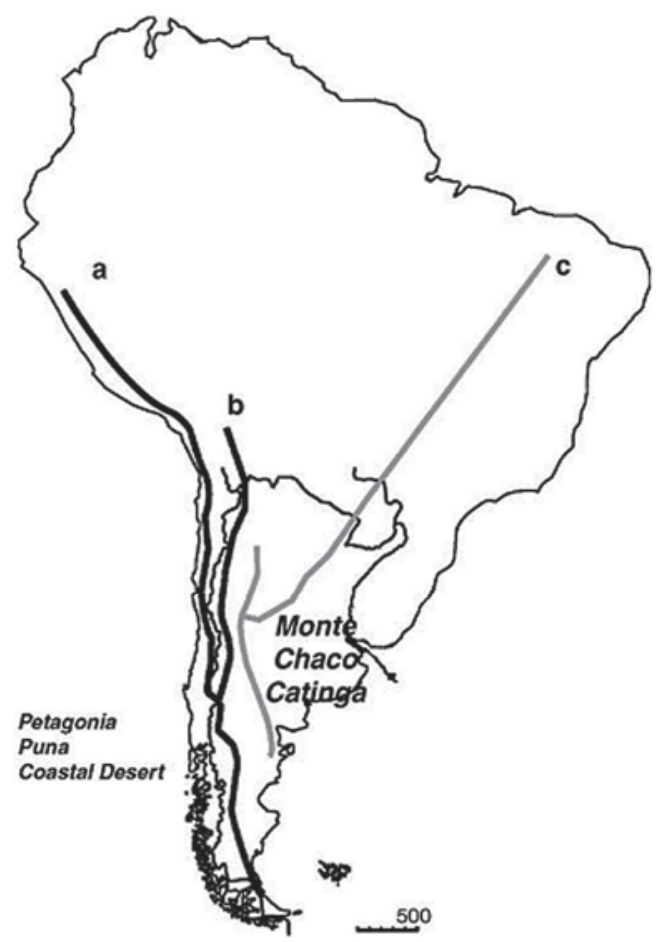

Fig. 24 - South American map with biotic tracks related to the xeric natural areas (modified from Roig-Juñent et al. 2003, 2006).

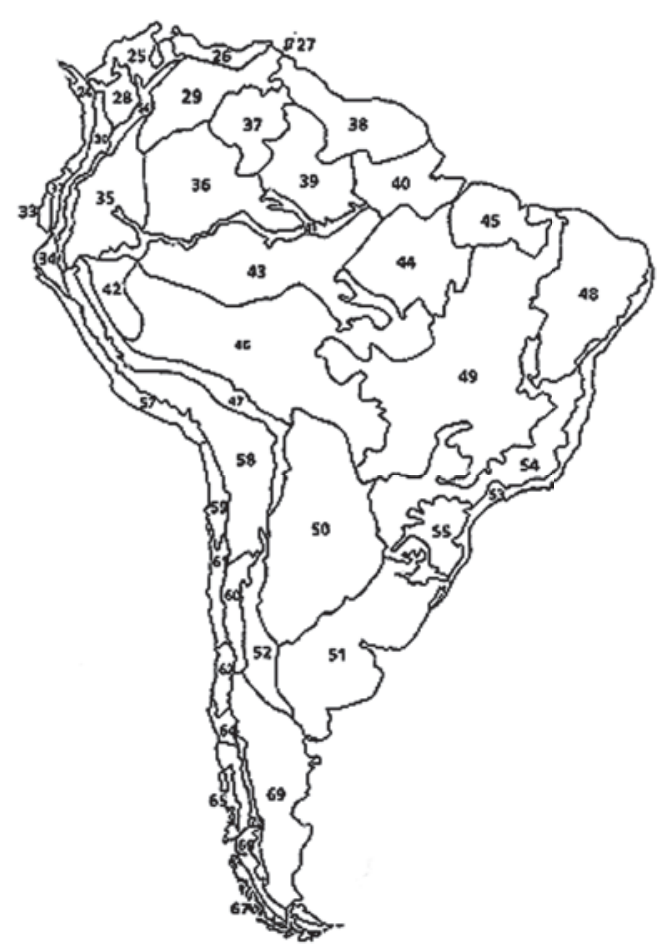

Fig. 25 - Map of biogeographic provinces (modified from Morrone 2006).

The biogeographic nodes coincided with the limits between the main plant formations of South America during the Pleistocene: node 1 coincided with the boundary between the grassland and open forest areas; and node 2 coincided with the boundary between the Brazilian open forest and open savanna areas. These patterns confirm the importance of the climate conditions in the distribution of the Late Pleistocene megafauna.

The GT 3 coincided with the transandine “corridor" proposed by Moreno et al. (1994), which could explain the presence of Hippidion saldiasi and Megatherium medinae in the transandine Chile, as well as in frontier of Chile-Argentina.

Comparing the generalized tracks (Fig. 22) with the regions and biogeographic provinces defined by Morrone (2006) on the basis of living taxa (Fig. 25), we verified that: GT 1 is delimited by Tumbes-Piura (area 34) and Coastal Peruvian Desert (area 57); GT 2, by Napo (area 35), Ucayali 
(area 42), Yungas (area 47), and Puna (area 58); GT 3, by Santiago (area 62); GT 4, by Pampa (area 51), Chaco (area 50), and Parana Forest (area 54); GT 5, by Araucaria angustifolia Forest (area 55), Parana Forest (area 54), Cerrado (area 49), and Caatinga (area 48); and GT 6, by Caatinga (area 48). This coincidence between tracks of living and fossil taxa suggests that certain recent biogeographic patterns were also present during the Late Pleistocene.

When we compared our results to other studies related to Pleistocene biogeography, we verified that the GTs 5 and 6 coincided with the Intertropical Region proposed by Cartelle (1999). According to this study, this region would house some megafauna taxa of pampean origin (e.g. Equus neogeus, Hippidion devillei, H. principale), but also present some endemic taxa (e.g. Parapanochthus and Hoplophorus) confirmed by the composition of GTs. However, the generalized tracks indicate the division of this region in two parts, with the node 2 showing the area where this division occurred.

The GTs 5 and 6 are partially in agreement with Costa et al. (2000), which point to an Atlantic Forest divided in two areas, and also coincided with the results of Carnaval and Moritz (2008), who defined two stable areas in the Atlantic Forest that remained unfragmented during the Pleistocene climatic changes.

The GT 2 coincided partly with some refugium areas proposed by Haffer (1969) and Prance (1982), situated in Bolivia and Peru. Although these areas possess some biogeographic meaning, the existence of refugia is debatable, because there are some evidences that Amazonia was never fragmented (Colinvaux et al. 2000).

The biogeographic node 1 is related to the contact between tropical and more temperate taxa and coincides with an area today composed by south Brazil, northwest Uruguay and Argentinian Mesopotamia (Missiones, Corrientes and Entre Rios provinces). According to Carlini et al. (2004) and Oliveira and Pereira (2009) it could be a contact zone between paleobiogeographic regions, with high biological diversity, supported by the presence of this node.

Overall, the generalized tracks and biogeographic nodes coincided with the limits between the main vegetal formations of South America during the Pleistocene (de Vivo and Carmignotto 2004). GT 3 coincided with the limit between the Argentinean desert and the Chilean open forest; part of the GT 4 coincided with the limits between the desert and steppe formations; node 1 coincided with the limit between the steppe and open forest formations; GTs 5 and 6 and node 2 coincided with limits between the great open savanna area in Brazil and the open forest formation. These data confirm the importance that vegetation and climate conditions had in the distributional patterns of herbivore megamammals during the Pleistocene in South America, and probably the changing on those conditions were the main cause for their extinctions.

\section{ACKNOWLEDGMENTS}

We thank Juan J. Morrone (Museo de Zoología, Facultad deCiencias, Universidad Nacional Autónoma de México-UNAM), Richard Fariña (Sección Paleontología, Facultad de Ciencias, Universidad de la República, Uruguay) and Ascanio D. Rincón (Instituto Venezolano de Investigaciones Científicas, IVIC, Venezuela) for providing valuable suggestions that contributed to improvements on this paper. We also thank Lílian P. Bergqvist and Lena Geise for critical comments to the Bachelor Monograph of the Rodrigo Pereira advised by Leonardo Avilla and Valéria Gallo, on which this paper is based.

This research was supported by grants from the Fundação Carlos Chagas de Amparo à Pesquisa do Estado do Rio de Janeiro (FAPERJ E-26/111.104/ 2008 and E-26/111.558/2008). V.G. has research fellowship grants from the Conselho Nacional de Desenvolvimento Científico e Tecnológico (CNPq - Brazil) and from the 'PROCIÊNCIA' (Rio de Janeiro State Government). B.A.A. has fellowship from Coordenação de Aperfeiçoamento de Pessoal 
de Nível Superior-CAPES (Brazilian Federal Government). R.C.L.P. had fellowship from CNPq (Brazilian Federal Government).

\section{RESUMO}

A distribuição geográfica de 27 espécies da megafauna de mamíferos herbívoros sul-americanos durante o Pleistoceno Superior foi analisada, visando à identificação de seus padrões de distribuição. Adistribuição das espécies foi estudada com o uso do método pan-biogeográfico de análise de traços. Seis traços generalizados (TGs) e dois nós biogeográficos foram obtidos. Os TGs não superpõem completamente com as áreas de savana aberta presentes no Pleistoceno, nem com os traços bióticos de alguns artrópodes típicos de clima árido, indicando que estes animais evitavam ambiente árido. De um modo geral, os TGs coincidiram com algumas das províncias biogeográficas definidas com base em táxons viventes, indicando que certos padrões de distribuição atuais já existiam no Pleistoceno. Os nós biogeográficos coincidiram com as bordas entre as principais formações vegetais do Pleistoceno, mostrando que o tipo de vegetação teve grande influência na distribuição da megafauna mamaliana. $\mathrm{O}$ nó 1 confirmou a existência de zonas de contato entre regiões paleobiogeográficas próximo à borda Argentina-Uruguai. O nó 2 conecta as regiões intertropicais brasileiras.

Palavras-chave: Padrões de distribuição, Biogeografia Histórica, Pan-biogeografia, Megafauna, Pleistoceno Superior, América do Sul.

\section{REFERENCES}

Alzate F, QuiJano-ABril MA AND Morrone JJ. 2008. Panbiogeographical analysis of the genus Bomarea (Alstroemeriaceae). J Biogeogr 35: 1250-1257.

ARZAMENDIA V AND GIRAUDO AR. 2009. Influence of large South American rivers of the Plata Basin on distributional patterns of tropical snakes: a panbiogeographical analysis. J Biogeogr 36: 1739-1749.

Behling H, ARZ HW, PÄtzold J AND Wefer G. 2002. Late Quaternary vegetational and climate dynamics in southeastern Brazil, inferences from marine cores GeoB 3229-2 and GeoB 3202-1. Palaeogeogr Palaeoclimatol Palaeoecol 179: 227-243.
CÂMARA IG. 2006. Reflexões sobre as extinções do Pleistoceno. In: GALLO V, BRITO PM, SILVA HMA AND FIGUEIREDO FJ (Eds), Paleontologia de Vertebrados: Grandes Temas e Contribuições Científicas, Rio de Janeiro: Editora Interciência, p. 153-171.

CAMPBEll Jr KE, FRAILEY CD AND ROMERO-PITTMAN L. 2000. The late Miocene gomphothere Amahuacatherium peruvium (Proboscidea: Gomphotheriidae) from the Amazonian Peru: Implications for the Great American Faunal Interchange. Instituto Geologico Minero y Metalurgico, Serie Estudios Regionales, 2000, 152 p. Boletin no. 23.

CAMPBell Jr KE, Prothero DR, ROMERo-PitTMAN L, HeRTEL F AND Rivera N. 2010. Amazonian magnetostratigraphy: Dating the first pulse of the Great American Faunal Interchange. J S Am Earth Sci 29: 619-626.

CARlini AA, ZURITA AE, Gasparini G AND Noriega JI. 2004. Los Mamíferos del Pleistoceno de la Mesopotamia argentina y su relación con los del Centro Norte de la Argentina, Paraguay y Sur de Bolivia, y los del Sur de Brasil y Oeste de Uruguay: Paleobiogeografía y Paleoambientes. In: ACEÑOLAZA FG (Coord), Temas de la Biodiversidad del Litoral fluvial argentino, Tucumán: Instituto Superior de Correlación Geológica, Serie Miscelánea no. 12, p. 83-90.

CARnaVAl AC AND MORITZ C. 2008. Historical climate modelling predicts patterns of current biodiversity in the Brazilian Atlantic forest. J Biogeogr 35: 1187-1201.

CARTElle C. 1999. Pleistocene mammals of the Cerrado and Caatinga of Brazil. In: EISENBERG JF AND REDFORD KH (Eds), Mammals of the Neotropics: The Central Neotropics: Ecuador, Peru, Bolivia, Brazil. Vol. 3, Chicago: The University of Chicago Press, p. 27-46.

Cavalcanti MJ AND Gallo V. 2008. Panbiogeographical analysis of distribution patterns in hagfishes (Craniata: Myxinidae). J Biogeogr 35: 1258-1268.

Cione AL, Tonni EP AND SoIBElzon LH. 2009. Did humans cause large mammal Late Pleistocene-Holocene extinction in South America in a context of shrinking open areas? In: HAYNES G (Ed), American Megafaunal Extinctions at the End of the Pleistocene, New York: Springer Publishers, Vertebrate Paleobiology and Paleoanthropology Series, p. 125-144.

Colinvaux PA, De Oliveira PE AND Bush MB. 2000. Amazonian and Neotropical plant communities on glacial time-scales: the failure of the aridity and refuge hypotheses. Quaternary Sci Rev 19: 141-169.

CORONA AMA, TOledo VH AND MORRONE JJ. 2009. Track analysis of the Mexican species of Buprestidae (Coleoptera): testing the complex nature of the Mexican Transition Zone. J Biogeogr 36: 1730-1738.

Costa LP, Leite YLR, Fonseca GAB AND FonseCA MT. 2000. Biogeography of South American forest mammals: Endemism and diversity in the Atlantic Forest. Biotropica 32(4b): 872-881. 
CRAW RC. 1982. Phylogenetics, areas, geology and the biogeography of Croizat: A radical view. Syst Zool 31: 304-316.

CRAW RC, GREHAN JR AND HEAdS MJ. 1999. Panbiogeography: Tracking the History of Life, New York: Oxford University Press, 229 p.

Croizat L. 1958. Panbiogeography or an Introductory Synthesis of Zoogeography, Phytogeography, Geology; with notes on evolution, systematics, ecology, anthropology, etc. Vol. 1 - The New World. Vol. 2 -The Old World. (Bound as 3 vols.). Caracas: Published by the Author, i-xxxi, 2755 p.

Crolzat L. 1964. Space, Time, Form: The Biological Synthesis. Caracas: Published by the Author, i-xix, 881 p. ("1962" on title page).

CrolzAT L. 1984. Mayr vs. Croizat: Croizat vs. Mayr - An enquiry. Tuatara 27: 49-66.

De Vivo M AND CARMignOTTO AP. 2004. Holocene vegetation change and the mammal faunas of South America and Africa. J Biogeogr 31: 943-957.

ECHEVERry A AND MORRONE JJ. 2010. Parsimony analysis of endemicity as a panbiogeographical tool: An analysis of Caribbean plant taxa. Biol J Linn Soc 101: 961-976.

ESPINOSA-PÉREZ MC, HENDRICKX ME AND MORRONE JJ. 2009. Identification of generalized tracks for the species of Isopoda (Peracarida) from the Eastern Pacific. J Crustacean Biol 29: 224-231.

ESRI INC. 1999. ArcView GIS version 3.2 for Windows. Redlands: Environmental Systems Research Institute.

Gallo V, Cavalcanti MJ And Silva HMA. 2007. Track analysis of the marine paleofauna from the Turonian (Late Cretaceous). J Biogeogr 34: 1167-1172.

Gallo V, Cavalcanti MJ, Silva RFL, Silva HMA AND PAGNONCELLI D. 2010. Panbiogeographical analysis of the shark genus Rhizoprionodon (Chondrichthyes, Carcharhiniformes, Carcharhinidae). J Fish Biol 2010: 1696-1713.

GREHAN JR. 2001. Panbiogeografía y la geografía de la vida. In: LLORENTE-BOUSQUETS J AND MORRONE JJ (Eds), Introduccion a la Biogeografía en Latinoamerica: Teorias, Conceptos, Metodos y Aplicaciones, México: Las Prensas de Ciencias, Facultad de Ciencias, Universidad Nacional Autónoma de México, DF, p. 181-195.

HAFFER J. 1969. Speciation in Amazonian forest birds. Science 165: 131-137.

HeAds M. 2004. What is a node? J Biogeogr 31: 1883-1891.

HeInE K. 2000. Tropical South America during the Last Glacial Maximum: evidence from glacial, periglacial and fluvial records. Quatern Int 72: 7-21.

KOCH PL AND BARNOSKY AD. 2006. Late Quaternary extinctions: State of the debate. Annu Rev Ecol Evol S 37: 215-250.

MARSHALL GL. 1988. Land Mammals and the Great American Interchange. Am Sci 76: 380-388.
MAYA-MARTínez A, SCHIMITTER-Soto JJ AND POZO C. 2011. Panbiogeography of the Yucatan Peninsule based on Charaxinae (Lepidoptera: Nymphalidae). Fla Entomol 94: 527-534.

MendozA PL. 2007. Tafonomía de los mamíferos extintos del Pleistoceno tardío de la costa meridional del semiárido de Chile (IV Regióon-32 $2^{\circ}$ latitud S). Alcances culturales y paleoecológicos. Rev Antropol Chil 39(1): 69-86.

Moreno PI, Villagrán C, MARQuet PA AND MARShall LG. 1994. Quaternary paleobiogeography of northern and central Chile. Rev Chil Hist Nat 67: 487-502.

Morrone JJ. 2001. Homology, biogeography and areas of endemism. Divers Distrib 7: 297-300.

Morrone JJ. 2004. Panbiogeografía, componentes bióticos y zonas de transición. Rev Bras Entomol 48: 149-162.

Morrone JJ. 2006. Biogeographic areas and transition zones of Latin America and the Caribbean islands based on panbiogeographic and cladistic analyses of the entomofauna. Annu Rev Entomol 51: 467-494.

Morrone JJ. 2009. Evolutionary biogeography: An integrative approach with case studies, New York: Columbia University Press, $301 \mathrm{p}$.

OliveIRA EV AND PEREIRA JC. 2009. Intertropical cingulates (Mammalia, Xenarthra) from the Quaternary of Southern Brazil: Systematics and paleobiogeographical aspects. Rev Bras Paleontol 12: 167-178.

PAGE RDM. 1987. Graphs and generalized tracks: Quantifying Croizat's Panbiogeography. Syst Zool 36: 1-17.

PRANCE GT. 1982. Biological diversification in the tropics, New York: Columbia University Press, 258 p.

RoIG-JUÑENT S, DOMÍNGUEZ MC, FLORES GE AND MATTONI C. 2006. Biogeographic history of South American arid lands: A view from its arthropods using TASS analysis. J Arid Environ 66: 404-420.

RoIG-JUÑEnt S, Flores GE AND Mattoni C. 2003. Consideraciones biogeográficas de la Precordillera (Argentina), con base en artrópodos epígeos. In: MORRONE JJ AND LLORENTE BOUSQUETS J (Eds), Una Perspectiva Latinoamericana de la Biogeografía, México: Las Prensas de Ciencias, Facultad de Ciencias, Universidad Nacional Autónoma de México, DF, p. 275-288.

RoJAs CA. 2007. Una herramienta automatizada para realizar análisis panbiogeográficos. Biogeografía 1: 31-33.

Salgado-Labouriau ML, Barbieri M, Ferraz-Vicentini KR AND PARIZZI MG. 1998. A dry climatic event during the late Quaternary of tropical Brazil. Rev Palaeobot Palyno 99: 115-129.

SÁNCHEZ B, Prado JL AND Alberdi MT. 2004. Feeding ecology, dispersal, and extinction of South American Pleistocene gomphotheres (Gomphotheriidae, Proboscidea). Paleobiology 30: 146-161.

SIMPSON GG. 1950. The history of the fauna of South America. Am Sci 38: 261-289.

SIMPSON GG. 1980. Splendid isolation: The curious history of South American mammals, New Haven: Yale University Press, 266 p. 
WeBB SD. 2006. The Great American Biotic Interchange: patterns and processes. Ann Miss Bot Garden 93: 245-257.

WeBB SD AND RANCY A. 1996. Late Cenozoic evolution of the Neotropical mammal fauna. In: JACKSON JBC, BUDD AF AND COATES AG (Eds), Evolution and Environment in Tropical America, Chicago: The University of Chicago Press, p. 335-358.

WoOdBuRne MO. 2010. The Great American Biotic Interchange: Dispersals, Tectonics, Climate, Sea Level and Holding Pens. J Mamm Evol 17: 245-264.
Woodburne MO, Cione AL AND Tonni EP. 2006. Central American provincialism and the Great American Biotic Interchange. In: CARRANZA-CASTAÑEDA Ó AND LINDSAY EH (Eds), Advances in late Tertiary vertebrate paleontology in Mexico and the Great American Biotic Interchange, México: Publicacíon Especial 4, Instituto de Geología and Centro de Geociencias, Universidad Nacional Autónoma de México, DF, p. 73-101. 